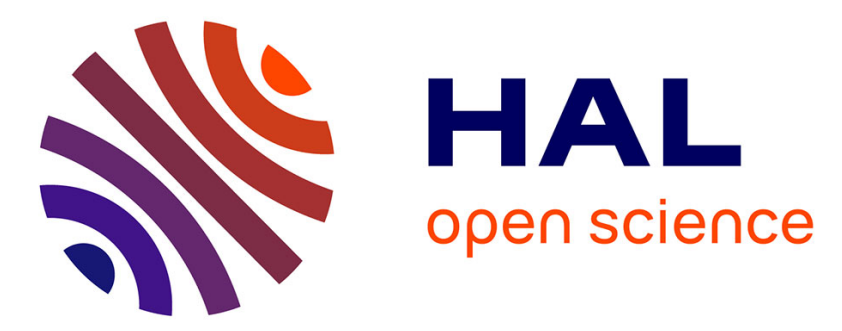

\title{
Genetic structure of quinoa (Chenopodium quinoa Willd.) from the Bolivian altiplano as revealed by RAPD markers
}

T. Winkel, Carmen del Castillo, Grégory Mahy, Jean-Philippe Bizoux

\section{- To cite this version:}

T. Winkel, Carmen del Castillo, Grégory Mahy, Jean-Philippe Bizoux. Genetic structure of quinoa (Chenopodium quinoa Willd.) from the Bolivian altiplano as revealed by RAPD markers. Genetic Resources and Crop Evolution, 2006, 54 (4), pp.897 - 905. 10.1007/s10722-006-9151-z . ird-03373203

\section{HAL Id: ird-03373203 \\ https://hal.ird.fr/ird-03373203}

Submitted on 11 Oct 2021

HAL is a multi-disciplinary open access archive for the deposit and dissemination of scientific research documents, whether they are published or not. The documents may come from teaching and research institutions in France or abroad, or from public or private research centers.
L'archive ouverte pluridisciplinaire $\mathbf{H A L}$, est destinée au dépôt et à la diffusion de documents scientifiques de niveau recherche, publiés ou non, émanant des établissements d'enseignement et de recherche français ou étrangers, des laboratoires publics ou privés. 


\title{
Genetic structure of quinoa (Chenopodium quinoa Willd.) from the Bolivian altiplano as revealed by RAPD markers
}

\author{
Carmen del Castillo $\cdot$ Thierry Winkel • \\ Grégory Mahy $\cdot$ Jean-Philippe Bizoux
}

Received: 11 January 2006/ Accepted: 25 April 2006/Published online: 7 December 2006

(C) Springer Science+Business Media B.V. 2006

\begin{abstract}
Quinoa (Chenopodium quinoa Willd.) is a pseudocereal originated from the Andes important for small farmers' food security as well as for commercial production. Recently, it has been claimed that in Bolivia genetic erosion could result from the marginalization of the crop in the north and from its commercial standardization in the south. The aim of this study was to quantify the hierarchical structure of the genetic variation present in eight quinoa field populations, consisting of cultivated and weedy individuals, representative of the altiplano and interandean valleys of Bolivia. Randomly amplified polymorphic DNA markers show that quinoa has a strong population structure and a high intra-population variation. An effect of geographical structure of the populations was highlighted, due to population isolation, not simply linked to distance but more probably to climatic and orographic barriers
\end{abstract}

C. del Castillo

Facultad de Agronomía, Universidad Mayor de San Andrés, La Paz, Bolivia

T. Winkel $(\square)$

IRD, UR 060 "'Climat et Fonctionnement des

Agroécosystèmes", La Paz, Bolivia

e-mail: thierry.winkel@ird.fr

G. Mahy · J.-P. Bizoux

Faculté Universitaire des Sciences Agronomiques, Laboratoire d'Écologie, Gembloux, Belgium present in the studied zone. The population structure is also reinforced by the limited seed exchanges among farmers as revealed by field interviews. This population structure appears related to three major biogeographic zones: the northern and central altiplano, the interandean valley, and the southern Salar. Intrapopulation genetic diversity was higher than that expected for a mainly autogamous species, and higher than that reported in anterior studies based on germplasm collections. These results are commented in view of current knowledge on phylogeny and reproductive biology of the species, and their implications regarding genetic resources management are discussed.

Keywords Bolivia Chenopodium quinoa . Genetic diversity · Genetic structure · RAPD

\section{Introduction}

In the Andean countries, quinoa represents a grain crop of large cultural and economic importance, especially in Bolivia where diverse institutions (e.g. the foundation PROINPA, the Agronomy Faculties of the State Universities of La Paz and Oruro) hold the most important germplasm banks in the world for this species, accounting for more than 2700 accessions. The morphophenological characteristics and the food 
uses of quinoa show that there is a huge diversity in varieties or local ecotypes (National Research Council 1989). The highest variation in cultivated quinoa is found near Lake Titicaca, between Cuzco (Peru) and Lake Poopó (Bolivia), and this is where scientists believe the crop was first domesticated (Gandarillas 1979; Pearsall 1992). During the last 20 years, the high plateau and the interandean valleys, primary centers of genetic diversity, have faced a considerable loss of agricultural biodiversity, particularly regarding marginal species and species neglected by agronomical research institutions (Brush 1998; Morlon 1996; Zimmerer 1996). Regarding quinoa, the success of the ecotype "Real" since about 15 years in the international market and the concurrence with other food products (pasta, rice, etc.) in the internal market are the cause of a strong erosion of the diversity in this crop, especially in the altiplano area (Hellin and Higman 2003; Laguna 2002). Apart from the possible losses of food, pharmaceutical or industrial usages, the reduction in genetic variability could be a risk for the adaptation of this species to the adverse conditions of the Andean agriculture, particularly the high unpredictability of the climate (François et al. 1999; Garcia et al. 2002). In the case of quinoa, studying genetic variation is essential to understand the organization of the biological diversity of the crop in function of its ecogeographic distribution. Indeed, the identification of genetically distinct groups is a prerequisite for the elaboration of conservation strategies as well as for the management of genetic resources in breeding programs.

The species Chenopodium quinoa Willd. includes both domesticated cultivars (subsp. quinoa) and free-living, weedy forms (subsp. milleanum or melanospermum) (Wilson 1981, 1988a-c). Domesticated and weedy quinoa populations are sympatric, and share a fundamentally autogamous reproductive system as well as a wide range of variation in leaf and grain size and color. Morphological traits, however, allow to distinguish both types, with domesticated plants showing adaptive features such as increased plant and grain size, condensated inflorescences, loss of seed dispersal and dormancy. Domesticated plants generally produce light-colored seeds, while weedy plants are always black-seeded. But the overall lack of molecular differentiation between domesticated and weedy populations make them considered as a monophyletic crop/ weed complex (Wilson 1988c, 1990).

The pattern of genetic diversity within and among field populations of quinoa has already been studied but only on the basis of a limited number of allozyme loci (e.g. Wilson 1981, $1988 \mathrm{a}-\mathrm{c})$, a feature that limits the generalization of those studies. In contrast to allozymes, RAPD markers (Random Amplified Polymorphic DNA) may provide a high number of genetic markers and have proven to be useful for the analysis of genetic structure in crop species. This technique has the advantages of being fast and easy, requiring little plant material, having high resolution without previous knowledge of DNA sequences (Nybom 2004). RAPD markers have been used by Ruas et al. (1999) to investigate the genetic variability of Chenopodium germplasm collections. They showed that wild and crop populations of C. quinoa share a low level of molecular variation, without differentiation between sympatric domesticated and weedy populations, and low levels of intraspecific variation within accessions. Caution should be taken in extrapolating these results to in situ genetic diversity conservation as it has been demonstrated that pattern of genetic diversity in germplasm collections does not necessarily reflect the extant genetic structure of landraces under cultivation (Doebley et al. 1985; Morden et al. 1989; Djé et al. 1999). For this reason, investigations on the pattern of genetic diversity of quinoa in situ are needed in order to orient conservation programs and monitor ongoing changes in the pattern of diversity.

In this paper, we investigated the population genetic structure of quinoa in three distinct regions of the altiplano and one interandean valley in Bolivia based on direct sampling in farmers' fields using RAPD markers. Our first aim was to assess the level of genetic diversity in field populations and its partition at three hierarchical levels (individuals, populations, ecoregions). In addition we compared the genetic diversity of weedy and cultivated quinoa types and discuss the level of genetic diversity still existing in currently cultivated quinoa populations. 


\section{Materials and methods}

Study sites and plant material

Bounded to the east and the west by the Andean cordilleras, the Bolivian altiplano stretches from the Lake Titicaca in the north $\left(16^{\circ} \mathrm{S}\right)$ to the Salar of Uyuni in the south $\left(21^{\circ} \mathrm{S}\right)$, covering an area of nearly $100.000 \mathrm{~km}^{2}$ at an altitude between 3600 and $4200 \mathrm{~m}$. Low and irregular rainfall, frequent frost and poor soils present severe limitations for agricultural production in the altiplano (Le Tacon et al. 1992; Vacher 1998). A north-south decreasing gradient of temperature and rainfall distinguishes three ecological sectors: the lake borders, the central altiplano, and the Salar region. A fourth agroecological sector linked to the altiplano is represented by the mesothermic interandean valleys dissecting the eastern cordillera. Eight quinoa populations were sampled, representative of these four agroecological sectors, with two populations per sector (Table 1, Fig. 1). These populations have most likely received different selection pressures from their different environments as well as during the domestication process which, in the case of the southern populations, was recently reactivated by the selection for grains conforming the commercial standards of the quinoa type "Real". In each population, seeds were collected on the panicles of 10 individual plants of the cultivated form, and 1-3 separate individuals of the weedy form ("ajara" in local dialect) when this black-seeded, shedding form was present. Within the plots, the individual plants were selected according to the relative proportion of the different morphotypes observable in the field (foliage and/or panicles of various colors or various forms). Seeds were germinated in a greenhouse (approximately $20^{\circ} \mathrm{C}$, and $70 \%$ of relative humidity, under natural illumination), and one seedling per family (i.e. originating from a given parent plant) was randomly sampled, cleaned of the blisters of oxalate covering the leaf epidermis, and stored at $-80^{\circ} \mathrm{C}$ until the extraction of DNA. On the whole, 87 progeny seedlings were sampled, of which 76 resulting from parents of the cultivated form and 11 from parents of the weedy form.

\section{DNA extraction and RAPD amplification}

DNA was extracted from frozen leaves using the DNeasy $^{\mathrm{TM}}$ (Qiagen, Germany) extraction kit. DNA amplification reactions were performed in $25 \mu$ total volume containing: $1 \times$ buffer, $1.5 \mathrm{mM}$ $\mathrm{MgCl}_{2}, 200 \mu \mathrm{M}$ of each Dntps (Invitrogen), $200 \mu \mathrm{g} / \mathrm{ml}$ of BSA (Aldrich), $1 \mathrm{U}$ of Taq DNA polymerase (Amersham Bioscience), $10 \mathrm{pmol}$ of primers (Operon Technologies), 20-30 ng of template DNA. A negative control without DNA was included in each reaction cycle. Amplifications were performed in a PTC 200 (MJ Research: Biozym) for an initial denaturing step at $95^{\circ} \mathrm{C}$ during $120 \mathrm{~s}$, for 44 cycles comprising a stage of denaturation of $20 \mathrm{~s}$ at $94^{\circ} \mathrm{C}$, a stage of hybridization of $60 \mathrm{~s}$ at $36^{\circ} \mathrm{C}$, a stage of elongation of $60 \mathrm{~s}$ at $72^{\circ} \mathrm{C}$, and finally a final elongation of $600 \mathrm{~s}$ at $72^{\circ} \mathrm{C}$. Amplification products were subjected to electrophoresis in $1.8 \%$ agarose gel containing ethidium bromide and then visualized under UV light. Ten primers (Operon technologies) were selected from an initial survey of 34 primers: OPA2, OPH-3, OPH-5, OPO-5, OPO-15, OPR-10, OPR-13, OPS-3, OPS-20 and OPT-7. Band selection was based on a repeatability test. DNA amplification for 24 individuals was repeated twice and only reproducible bands were considered for analysis.

Table 1 Location of the sampling sites for the study of quinoa population genetic structure in the Bolivian altiplano

\begin{tabular}{|c|c|c|c|c|}
\hline Population & Ecological sector & Location & Altitude (m) & Longitude E-Latitude S \\
\hline njo & North (lake) & Pacharia & 3909 & $68^{\circ} 52^{\prime} 60^{\prime \prime}-15^{\circ} 53^{\prime} 03^{\prime \prime}$ \\
\hline nra & North (lake) & Japuraya & 3835 & $68^{\circ} 43^{\prime} 59^{\prime \prime}-16^{\circ} 03^{\prime} 06^{\prime \prime}$ \\
\hline cep & Center (plain) & Sivicani & 3746 & $68^{\circ} 08^{\prime} 52^{\prime \prime}-16^{\circ} 59^{\prime} 30^{\prime \prime}$ \\
\hline cig & Center (plain) & Park'o & 4172 & $68^{\circ} 31^{\prime} 01^{\prime \prime}-16^{\circ} 57^{\prime} 22^{\prime \prime}$ \\
\hline $\sin$ & South (salar) & Karuta & 3684 & $67^{\circ} 54^{\prime} 10^{\prime \prime}-19^{\circ} 37^{\prime} 51^{\prime \prime}$ \\
\hline sjl & South (salar) & Pachincha & 3713 & $67^{\circ} 39^{\prime} 36^{\prime \prime}-20^{\circ} 46^{\prime} 27^{\prime \prime}$ \\
\hline vjd & Interandean valley & Ujti Churo & 3242 & $65^{\circ} 18^{\prime} 29^{\prime \prime}-19^{\circ} 40^{\prime} 41^{\prime \prime}$ \\
\hline vse & Interandean valley & Sepultura-Puna & 3627 & $65^{\circ} 35^{\prime} 29^{\prime \prime}-19^{\circ} 51^{\prime} 23^{\prime \prime}$ \\
\hline
\end{tabular}


Fig. 1 Localization of the 8 sampled quinoa populations of Bolivia (labels on the map correspond to the population codes in Tables 1 and 2)

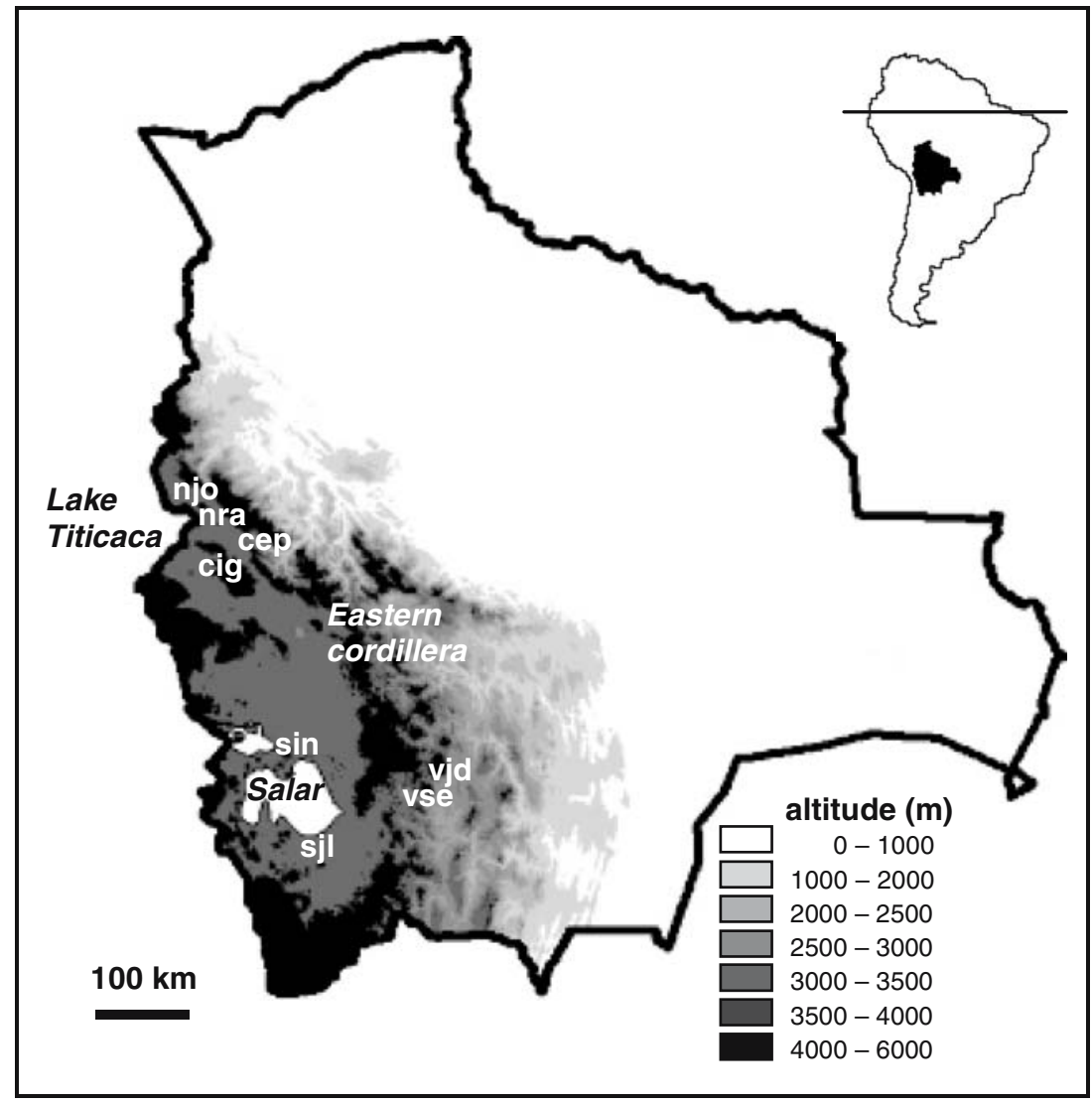

Data analysis

The absence/presence (0/1) of the 38 selected bands was determined for the 87 individuals. Bands of identical size amplified with the same primer were considered to be homologous. The proportion of polymorphic loci and averaged genetic diversity $(\mathrm{He})$ were estimated for each population and for each form by pooling individuals by form (weedy and cultivated) with Arlequin software version 2.0 (Schneider et al. 2000).

The genetic differentiation between weedy and cultivated forms was tested with an AMOVA (Excoffier et al. 1992) with all the individuals pooled in two groups, weedy and cultivated, independently of the stand origin. To examine the level of genetic differentiation among populations, AMOVA was used to separate the genetic variance at three hierarchical levels: within populations, among populations, among ecoregions, using Arlequin version 2.00. Significance was tested on the basis of 10,000 random permutations (Schneider et al. 2000).

In order to test for isolation by distance, the relationship between pairwise $F_{\text {st }}$ value derived from AMOVA computation and the pairwise geographical distance for all pairs of populations was tested with a Mantel test, using Arlequin version 2.00. To examine with more details the pattern of genetic relationships among the sampled individuals, an UPGMA dendrogram of all individuals was constructed on the dissimilarity matrix (DICE index) between individuals calculated by XL-STAT ver 6.0.

\section{Results}

Genetic diversity of the populations

The proportion of polymorphic sites per population varied from $24.0 \%$ to $60.5 \%$ with an average at the population level of $45.4 \%$ (Table 2). The 
genetic diversity index $(\mathrm{He})$ of the individual populations varied from 0.104 to 0.215 with an average of 0.165 (Table 2). There was no obvious difference in genetic diversity between the two forms of quinoa, with indexes $\mathrm{He}$ of $0.288 \pm 0.160$ for the weedy form and $0.311 \pm 0.157$ for the cultivated form. Regarding ecoregions, there were no obvious differences in genetic diversity either.

Differentiation between weedy and cultivated forms

When individuals were grouped according to the form (cultivated or weedy), $8.6 \%(P<0.001)$ of the total variability was due to differences between forms and $91.4 \%$ to the variation within forms based on the AMOVA analysis. Despite this significant global differentiation between the two forms, individuals did not grouped according to the form in the UPGMA dendrogram of individuals (Fig. 2). The individuals of the weedy form tended to group with those of the cultivated form which belong to the same ecoregional group. This is the case for individuals NJO01 and NJO02 within the group A "northern and central altiplano", for individuals VSE01, VSE02 and VSE03 within the group B "interandean valley", and individuals SJL01, SJL02, SJL03, SIN01, SIN02, SIN03 within the group C "southern altiplano". As such, there was no clear separation between weedy and cultivated forms.

Table 2 Genetic diversity within 8 quinoa populations of the Bolivian altiplano

\begin{tabular}{lll}
\hline Population & $\begin{array}{l}\text { Percentage } \\
\text { of polymorphic } \\
\text { bands }\end{array}$ & $\begin{array}{l}\text { Average genetic } \\
\text { diversity } \mathrm{He} \pm \\
\text { standard } \\
\text { deviation }\end{array}$ \\
\hline njo & 55.3 & $0.182 \pm 0.104$ \\
nra & 44.7 & $0.143 \pm 0.085$ \\
cep & 47.4 & $0.149 \pm 0.089$ \\
cig & 24.0 & $0.104 \pm 0.064$ \\
sjl & 60.5 & $0.208 \pm 0.117$ \\
sin & 42.1 & $0.191 \pm 0.110$ \\
vjd & 55.3 & $0.215 \pm 0.123$ \\
vse & 34.2 & $0.125 \pm 0.074$ \\
Average between & 45.44 & 0.165 \\
populations & & $0.311 \pm 0.157$ \\
Cultivated forms & 89.5 & $0.288 \pm 0.160$ \\
Weedy forms & 71.1 & \\
\hline
\end{tabular}

Genetic structure of the populations

The analysis of the genetic structure of the populations was carried out twice: first by including the weedy individuals in the populations, secondly by not taking into account these individuals. The results obtained were not significantly different. Because of the weak differentiation between weedy and cultivated forms, only the results related to the whole set of individuals, i.e. including the weedy form are presented.

Of the total molecular variance, $27.1 \%$ $(P<0.001)$ was due to differentiation among ecoregions, $25.2 \% \quad(P<0.001)$ to differentiation among populations within ecoregions and $48.7 \%$ to within population variation. Genetic differentiation $\left(F_{\text {st }}\right)$ between populations pairs ranged from 0.115 to 0.699 (mean $\pm \mathrm{SD}=0.287 \pm 0.094$, $\mathrm{CV}=32.8 \%)$. All the pairwise $F_{\text {st }}$ values were significant. The pairwise values of $F_{\text {st }}$ among the 8 populations were statistically correlated with pairwise geographic distances (Mantel test: $r=0.28, P=0.016)$. Nevertheless, the value of the coefficient of correlation was low, and the proportion of the variation in the matrix of $F_{\text {st }}$ explained by the geographical distance $\left(r^{2}\right)$ was only $7.8 \%$.

The UPGMA dendrogram of individuals exhibited three main groups (Fig. 2). The group A mainly included individuals of the northern and the central altiplano, with a distinction between two subgroups, one consisting of individuals from a northern altiplano population riverine of Lake Titicaca (njo) and individuals of a population of the central plain (cep), the other one consisting of individuals from a riverine population of the lake (nra) and individuals from a population of an elevated sector of central altiplano (cig). Within each of these subgroups individuals clustered according to their population. In this group also appeared two individuals of a valley population (vjd11 and vjd12). The second cluster (group B) only contained individuals from the valley of Potosi (vjd and vse), with a mixing of the individuals of the two populations. In the third cluster (group C) only individuals from the southern altiplano (sjl and sin) were present. Those individuals tend to group according to their population of origin but the trend was less clear than for group A. Thus, the 
Fig. 2 UPGMA dendrogram of the 87 quinoa plants genotyped by RAPDs (group A: northern and central altiplano, group B: interandean valley, group C: southern altiplano)

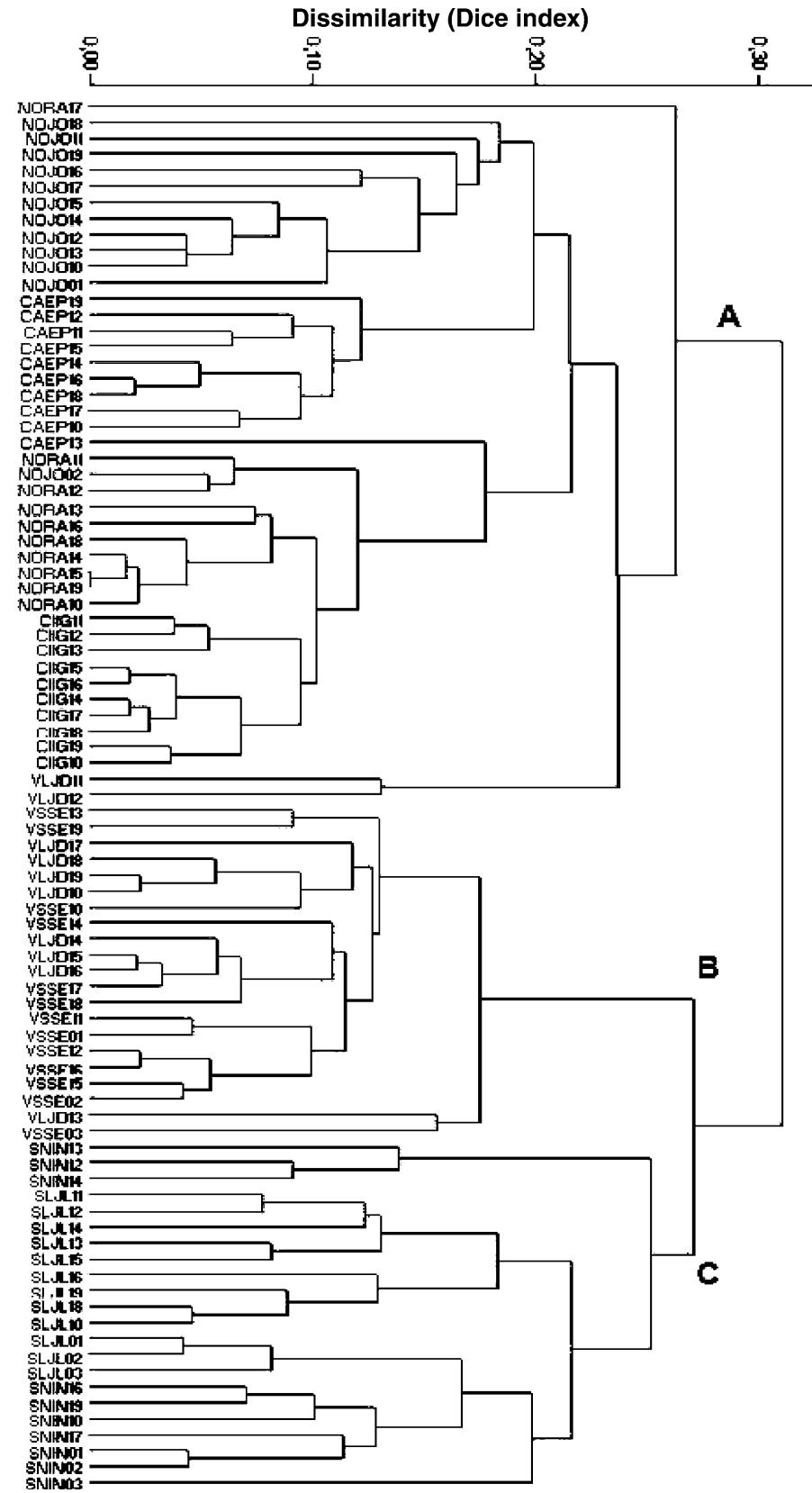

structure of the dendrogram as a whole corresponded to individuals grouping according simultaneously to their population and geographical origin, although the individuals of the two valley populations (vjd and vse) mixed in a single group, with two individuals reclassified out of their population group. This suggested an overall genetic structure with relatively homogeneous and genetically isolated populations.

\section{Discussion}

Genetic diversity

All the quinoa populations examined in this study exhibited within population polymorphism for RAPD markers, a situation strongly divergent from the high allozyme monomorphism exhibited by Andean cultivated quinoa 
populations studied by Wilson (1981) with 13 populations out of 26 which exhibited no variation at five allozyme loci. The mean proportion of polymorphic loci in Andean populations studied by Wilson (1981) was $12 \%$ (recalculated from original data) as compared to our mean proportion of $45 \%$ based on RAPD. Even if comparisons between studies based on allozymes and RAPD should be treated cautiously, as allozymes and RAPD are generally not similarly sensitive (Fritsch and Rieseberg 1996) particularly for allozyme studies using a limited number of loci, our results point to the fact that cultivated populations of quinoa exhibited a much higher genetic variation than has been reported previously. We also found unexpected high indices of average genetic diversity within populations (mean $\mathrm{He}=0.165$ ) when compared to mean values for RAPD studies in other autogamous species (ca. 0.09 according to Nybom and Bartish 2000). Genetic diversity of quinoa populations was more comparable to the mean diversity observed with RAPD in allogamous species or species with mixed reproduction system (0.22-0.26 according to Nybom and Bartish 2000). Both the tetraploid origin of the species and marginal rate of cross fecundation (generally less than $10 \%$, see Bonifacio et al. 2001) may help to account for the maintenance of the genetic diversity in spite of the predominant self pollination and genetic drift possibly mediated by planting bottleneck (Wilson 1981).

Another interest of our study regarding genetic diversity was to reveal the available genetic variation in the populations from the Salar region (southern altiplano) represented by the quinoa type "Real" selected for morphological conformation of the grains. Though our sample was limited to 20 individuals from 2 populations, it can be stated from our observations that those populations did not go through a genetic bottleneck. This suggests that selection for grain conformation has not directly influenced the potential to maintain genetic variability. This is especially important when considering the adaptation potential of the species to harsh and unpredictable environmental conditions.
Comparison between weedy and cultivated forms of quinoa

Previous studies comparing weedy and cultivated forms of quinoa have been based on accession comparisons (Ruas et al. 1999) or comparison of pure populations of each form (Wilson 1981, 1988a-c). Here, we considered a comparison among individuals of the two forms, growing sympatrically within cultivated fields. Neither previous accessions studies nor previous field population studies have substantiated the taxonomic separation of weedy and cultivated forms of $C$. quinoa. Our results conformed to this conclusion as we observed a significant but very low level of global differentiation between the two forms. On the contrary, the differentiation among populations was much more important than the differentiation between forms, which could be explained by the significant gene flows between weedy and cultivated quinoa measured at the field level (Samañez 1977; Wilson and Manhart 1993). Moreover, we found that the individuals of the weedy form were closer to those of the cultivated form of the same ecoregion than they were to a weedy form of another ecoregion. Studies of accessions (Ruas et al. 1999) and field populations (Wilson 1981, 1988a-c, the present study) are then convergent to consider the Andean quinoa crop/weed complex as a monophyletic co-evolving unit. In addition, the global level of genetic diversity in cultivated quinoa was similar to that found in the weedy form.

\section{Genetic structure}

All our results were coherent to show a strong genetic differentiation among the studied populations. Taken as a whole, in a vast geographical area, the populations of quinoa showed a pattern of genetic differentiation related to the regional ecogeography with a small proportion of the variation explained by the geographical distance. The effect of the geographical distance was partly masked by the higher genetic proximity of the populations of the northern and central ecoregions compared to the other ecoregions. This is translated on the dendrogram by the clustering of the individuals of these ecoregions, 
whereas the populations and the individuals of the other ecoregions grouped strictly according to their particular ecoregion (valley or southern altiplano).

High genetic differentiation among fields is consistent with the mainly autogamous reproduction of the species. Limited seed exchange among geographically isolated regions is also probably a factor of differentiation as well as the cultivation practices of farmers. Based on an interview of 98 farmers across the Bolivian altiplano (Del Castillo 2002-2003, unpublished) it appeared that $96 \%$ of the farmers in the interandean valley and the Salar region sow their fields with seeds harvested on their own farm, while this percentage falls to $69 \%$ and $59 \%$ in the northern and central altiplano, respectively. In these two sectors, local markets as well as agricultural extension institutions are alternative sources of quinoa seeds. These data suggest that genetic exchanges are more important in the northern and central altiplano in comparison with the other two regions.

During the modern times, land reforms, massive migrations of peasants towards the cities, and international trade were factors that affected the genetic diversity pattern of quinoa, which may lead to a loss of local varieties and a standardization of the commercial production (Laguna 2002; Zimmerer 1996). In spite of these recent factors of genetic erosion, our analysis of the genetic variation of quinoa on several levels of biological organization indicated that an important interpopulation diversity still exists in the Bolivian altiplano. It corresponds mainly to the geographical and climatic differentiation of the area of cultivation, and leads to differentiate quinoa of the northern and central altiplano, quinoa of the valleys, and quinoa of the Salar (or southern altiplano). Such a conclusion could not have been reached based on information from germplasm collections. Indeed, Ruas et al. (1999) reported a low level of intraspecific variation among germplasm accessions of quinoa (originating mainly from Bolivia) based on RAPD markers. Discrepancies between genetic structure of field populations and germplasm accessions have already been reported in other studies (Djé et al. 1999). According to Doebley et al. (1985),
Morden et al. (1989), Djé et al. (1999), this may result from different factors: (1) low sample size at the accession level, (2) genetic bottleneck during sampling and reproduction procedure in germplasm collection, and (3) different geographic scale between genebank and in situ studies. This points to the importance of examining crop genetic variation in field populations for genetic conservation.

As far as in situ conservation practices are concerned, our results suggest that individual fields are not per se valuable units of conservation as, on average, less than $50 \%$ of the total neutral genetic variation occurs within fields. In situ conservation of the quinoa genetic diversity will require maintaining a network of selected fields based on a hierarchical strategy with a protection of a set of fields in each ecoregion. Our results also suggest that current germplasm collections may not be representative of the genetic variation of the quinoa complex and that further sampling for ex situ conservation will also have to take into account the hierarchical structure of the genetic variation.

Acknowledgements We would like to thank the Bolivian farmers and extension agents met during our prospections for the generous provision of quinoa material. We also thank Gaëtan Rochez for its skillful assistance in the laboratory, and Sam Geerts for improving the quality of the text. This work was co-financed by the "Institut de Recherche pour le Développement" (IRD, french institute of scientific cooperation) and the "Faculté Universitaire des Sciences Agronomiques" of Gembloux (Belgium). CDC gratefully acknowledges the support of a doctoral grant of the "Département Soutien et Formation" of the IRD.

\section{References}

Bonifacio A, Mujica A, Alvarez A, Roca W (2001) Mejoramiento genético, germoplasma y producción de semillas. In: Mujica A, Jacobsen SE, Izquierdo JI, Marathée JP (eds) Quinua (Chenopodium quinoa Willd.): ancestral cultivo andino, alimento del presente y futuro. CD-Rom: Cultivos Andinos Version 1.0. FAO, Santiago Chile

Brush SB (1998) Crop diversity in mountain areas and conservation strategy. Rev Géogr Alpine 4:115-130

Djé Y, Forcioli D, Ater M, Lefèbvre C, Vekemans X (1999) Assessing population genetic structure of sorghum landraces from north-western Morocco using allozyme and microstallite markers. Theor Appl Genet 99:157-163 
Doebley JF, Goodman MM, Stuber CW (1985) Isozyme variation in the races of maize from Mexico. Am J Bot 72:629-639

Excoffier L, Smouse PE, Quattro M (1992) Analysis of molecular variance inferred from metric distances among DNA haplotypes: application to human mitochondrial DNA restriction data. Genetics 131:479-491

François C, Bosseno R, Vacher JJ, Seguin B (1999) Frost risk mapping derived from satellite and surface data over the Bolivian altiplano. Agric For Meteor 95:113-137

Fritsch P, Rieseberg LH (1996) The use of random amplified polymorphic DNA (RAPD) in conservation genetics. In: Smith TB, Wayne RK (eds) Molecular genetic approaches in conservation. Oxford University Press, New York USA, pp 54-73

Gandarillas H (1979) Genética y origen. In: Tapia ME et al (eds) Quinua y kañihua, cultivos andinos. IICA, Bogota, Colombia, pp 45-64

Garcia M, Raes D, Jacobsen SE (2002) Evapotranspiration analysis and irrigation requirements of quinoa (Chenopodium quinoa) in the Bolivian highlands. Agric Water Manag 1799:1-16

Hellin J, Higman S (2003) Quinoa and food security. In: Hellin J, Higman S (eds) Feeding the market: South American farmers, trade and globalization. Intermediate Technology Development Group (ITDG) Publishing, London UK, pp 131-168

Laguna P (2002) Competitividad, externalidades e internalidades, un reto para las organizaciones económicas campesinas: la inserción de la Asociación Nacional de Productores de Quinua en el Mercado mundial de la quinua. Debate Agrario, Centro Peruano de Estudios Sociales (CEPES) 34:95-169

Le Tacon P, Vacher JJ, Eldin M, Imaña E (1992) Los riesgos de helada en el Altiplano boliviano. In: Morales D and Vacher JJ (eds) Actas del VII Congreso Internacional sobre Cultivos Andinos. Orstom, La Paz, Bolivia, pp 287-291

Morden CW, Doebley J, Scherts KF (1989) Allozyme variation in old world races of Sorghum bicolor (Poaceae). Am J Bot 76:247-255

Morlon P (1996) Comprender la agricultura campesina en los Andes Centrales, Perú y Bolivia. IFEA, CBC, Lima, Perú

National Research Council (1989) Lost crops of the Incas: little-known plants of Andes with promise for worldwide cultivation. National Academy Press, Washington, USA
Nybom H (2004) Comparison of different nuclear DNA markers for estimating intraspecific genetic diversity in plants. Mol Ecol 13:1143-1155

Nybom H, Bartish IV (2000) Effects of life history and sampling strategies on genetic diversity estimates obtained with RAPD markers in plants. Evol System 3:93-114

Pearsall DM (1992) The origins of plant cultivation in South America. In: Cowan CW, Watson PJ (eds) The origins of agriculture. Smithsonian Institution Press, Washington, USA, pp 173-205

Ruas PM, Bonifacio A, Ruas CF, Fairbanks DJ, Andersen WR (1999) Genetic relationship among 19 accessions of six species of Chenopodium L., by Random Amplified Polymorphic DNA fragments (RAPD). Euphytica 105:25-32

Samañez R (1977) Biología floral en dos líneas de quinua (Chenopodium quinoa Willd.). Thesis Ing. Agro. Facultad de Agronomía, Universidad Nacional del Altiplano, Puno, Perú

Schneider S, Roessli D, Excoffier L (2000) Arlequin Ver. 2.0: a software for populations genetics data analysis. University of Geneva, Switzerland

Vacher JJ (1998) Responses of two main Andean crops, quinoa (Chenopodium quinoa Willd.) and papa amarga (Solanum juzepczukii Buk.) to drought on the Bolivian altiplano: significance of local adaptation. Agric Ecosyst Environ 68:99-108

Wilson HD (1981) Genetic variation among South America populations of tetraploid Chenopodium sect. Chenopodium subsect. Cellulata. Syst Bot 6:380-398

Wilson HD (1988a) Allozyme variation and morphological relationship of Chenopodium hircinum (s.l.). Syst Bot 13:215-228

Wilson HD (1988b) Quinua biosystematics. I: domesticated populations. Econ Bot 42:461-477

Wilson HD (1988c) Quinua biosystematics. II: free-living populations. Econ Bot 42:478-494

Wilson HD (1990) Quinua and relatives (Chenopodium sect. Chenopodium subsect. Cellulata). Econ Bot 44:92-110

Wilson HD, Manhart J (1993) Crop/weed gene flow: Chenopodium quinoa Willd. and C. berlandieri Moq. Theor Appl Genet 86:642-648

Zimmerer KS (1996) Changing fortunes: biodiversity and peasant livelihood in the Peruvian Andes. University of California Press, Berkeley, USA 